\title{
The Role of Mining in the South African Economy
}

Johannes Fedderke and Farah Pirouz

Econometric Research Southern Africa and School of Economic and Business Sciences, University of the Witwatersrand

ABSTRACT

This paper examines the contribution of three aggregate mining sectors of the South African economy to output and employment over the 1970-97 period. The finding of a declining importance of mining in output and employment creation must be sectorally differentiated. Gold and Uranium Mining is the chief source of these declines, while evidence for Coal and Diamond and Other Mining is more modulated. We find strong redistribution of output from equity to labour over the course of the 1990s for Gold and Uranium Mining. In mining labour markets, we present developments in employment trends, in real labour cost, and in labour productivity. We examine links between these dimensions in an explanation of changing employment trends. We conclude with a VECM estimation of a labour requirements equation to corroborate our findings.

JEL Q30

\section{INTRODUCTION}

Conventional wisdom views the mining sector of the South African economy as its quintessence. As contributor to aggregate output, as foreign exchange earner for the economy, as employer, and as a generator of tax revenues, mining has often been viewed as the locomotive of South Africa's economic development.

Historically such a perception certainly carries much validity. In this paper we examine whether this perception of the role of mining in the South African economy remains justified and to what extent the role of mining in the economy has changed. Various sources have noted the declining contribution of the mining sector to gross domestic product (GDP) and employment in South Africa. ${ }^{2}$

We focus on output and employment since they have the most immediate and dramatic welfare impact on the South African economy. ${ }^{3}$ The mining industry 
has been declining both in terms of its importance as an employer relative to other sectors in the economy, and in terms of the absolute level of employment that it provides. Such job losses have largely affected unskilled workers. We examine possible reasons for the declining importance of mining as an employer. One immediate candidate is the declining level of value added generated by the mining sector that could translate into a declining demand for labour. Examination of the evidence suggests that, at best, output levels are a partial explanation of declining employment trends in the mining sectors. The decline in the share of mining in total output of the South African economy has been far more dramatic than the share of mining in the total formal sector employment of the economy.

Two further possible explanations for employment trends in South Africa's mining sectors are therefore examined: real labour cost and real labour productivity. Exploratory examination of the evidence suggests that real labour cost for all three mining sectors demonstrates the negative correlation with employment that economic theory would predict. Increases in real labour productivity have not been sufficient to warrant the increases in real labour cost observed for the mining sectors, nor have they been justified by an increasing skills mix of the mining sector's labour force. Finally, prices are unlikely to feature as explanations of employment trends in these sectors.

The role of mining in the economy has thus become more modulated. Whereas in a few of its traditionally pivotal roles it remains in much the same position, in most areas it is considerably less important than it used to be. Mining in the South African economy has been in a process of profound transformation for a period now spanning well over two decades. Such transformation of the role of the mining sector should be seen as a natural process. Any economy that considers itself on a developmental trajectory would experience diversification of economic activity over time.

The investigation that follows contains two sections. In the first, we examine the contribution of the aggregate mining sector to the total output of the South African economy. In the second, we explore the role of mining in the South African labour market. A final section concludes.

Whereas aggregate data on the South African mining sector was readily available, more detailed data for certain sub-sectors was more difficult to collect. Readers should bear in mind that while providing additional information, the use of a range of different data sources is likely to bring about some loss in consistency. Details about the data used in the different sections of the document and its description are presented in a summary of data sources in the appendix. 


\section{THE CONTRIBUTION OF THE MINING SECTOR TO AGGREGATE OUTPUT OF THE SOUTH AFRICAN ECONOMY}

This section explores the details of the declining relative and absolute importance of mining in terms of its contribution to aggregate output over the 1970-98 period. The three aggregate mining sectors: Coal, Gold and Uranium, and Diamond and Other Mining are analysed in terms of their contribution to total value added in the South African economy, total tax revenue, and export earnings. A final subsection investigates the distribution of output between the factors of production employed by the three mining sectors.

\subsection{The Importance of Mining in terms of its Contribution to Value Added in the South African Economy}

In this section we examine the contribution of the mining sector to South African output in terms of the real value added contributed by the three aggregate South African mining sectors. As such our concern is with the net contribution of the mining sectors to aggregate output in the South African economy, rather than with the aggregate volume of sales of the sector. ${ }^{5}$

Over the $1970-98$ period, the proportional contribution of the mining sector to total value added in the South African economy has more than halved, declining from 21.3 per cent in 1970 , to 9.9 per cent of the private sector's GDP in 1998 see the evidence of Table 1. The strongest decrease in the proportional contribution of mining to total value added of the economy occurred during the 1970-75 period. While the decrease continued thereafter, it has been at a far slower rate. It is noteworthy that it is the service sector that has increased its proportion of GDP to over 45 per cent after 1995, primarily at the expense of the mining sector.

Table 1 Contribution to private sector gross domestic product by economic sector

\begin{tabular}{|l|c|c|c|c|c|c|c|}
\hline & 1970 & 1975 & 1980 & 1985 & 1990 & 1995 & 1998 \\
\hline Agric, Forest and Fish & 5.4 & 5.4 & 5.7 & 5.4 & 6.1 & 5.3 & 6.4 \\
\hline Total Mining & 21.3 & 13.9 & 13.3 & 13.0 & 11.3 & 10.5 & 9.9 \\
\hline Total Manufacturing & 27.5 & 30.1 & 32.8 & 29.4 & 29.6 & 29.3 & 28.3 \\
\hline $\begin{array}{l}\text { Electricity, Gas and } \\
\text { Water }\end{array}$ & 2.6 & 3.1 & 3.6 & 4.6 & 5.1 & 5.6 & 5.9 \\
\hline $\begin{array}{l}\text { Building and } \\
\text { Construction }\end{array}$ & 5.5 & 6.3 & 5.0 & 4.4 & 4.0 & 3.4 & 3.3 \\
\hline Services & 37.8 & 41.1 & 39.6 & 43.2 & 43.9 & 45.9 & 46.3 \\
\hline
\end{tabular}

Note: Figures are in percentages, and may not add up due to rounding 
In order to obtain a closer understanding of the declining relative importance of mining in the economy, Table 2 depicts the proportional contributions to GDP of the three principal mining sub-sectors. ${ }^{6}$

Table 2 Contribution of the three principal mining sectors to private sector GDP

\begin{tabular}{|l|c|c|c|c|c|c|}
\hline & 1970 & 1980 & 1985 & 1990 & 1993 & 1998 \\
\hline Coal & 1.1 & 1.5 & 2.7 & 2.0 & 1.5 & 1.9 \\
\hline Gold and Uranium & 17.2 & 8.4 & 7.1 & 5.7 & 7.3 & 4.1 \\
\hline Diamond and Other & 3.0 & 3.3 & 3.3 & 3.6 & 3.0 & 3.1 \\
\hline Total & 21.3 & 13.3 & 13.0 & 11.3 & 11.8 & 9.9 \\
\hline
\end{tabular}

Note: Figures are percentages, and may not add up due to rounding

What emerges from the evidence is that the declining importance of mining as a proportion of total output in the economy is chiefly attributable to the declining importance of the Gold and Uranium Mining sector. While still contributing 17.2 per cent of the private economy's output in 1970, its proportional contribution to private sector GDP had fallen to 4.1 per cent by 1998 . The two other aggregate mining sectors marginally increased their relative share of private sector GDP in the same period to $1998 .^{7}$

Of course, a declining relative importance of mining does not have to entail a declining absolute importance. A falling proportion to total value added in the economy is consistent with rising absolute contributions to value added in the economy. It is therefore important to note that the decline in the importance of Gold and Uranium Mining in the South African economy, is not only one of a declining relative importance but also one of falling absolute output levels in real terms when computed in terms of sectoral deflators (See Figure 1). Second, while the decline in Gold and Uranium Mining has been dramatic, it has also been relatively unidirectional, with few reversals in the decline of absolute output over time.

Note that the decline in Gold and Uranium Mining is likely to have been due to structural factors in the sector, rather than changes in the gold price. Since the gold price has shown both sharp increases, and sharp decreases in US-Dollar terms over the sample period, it is difficult to argue that the monotonically declining value added of the gold mining industry is due to changes in the gold price. Figure 2 illustrates. The gold price in Rand terms has - due to the depreciating exchange rate - steadily increased over the period 1970 to 1998 , particularly after 1992 . Hence, the gold price does not serve as a convincing explanation for declining output in Gold and Uranium Mining. The observed 
fall in the Rand gold price from 1996 to 1997 by 8.6 per cent may have contributed to the recent dramatic output decreases.

Figure 1 Gold and Uranium Mining: Comparison of Real Output deflated by Sectoral and Aggregate GDP Deflators

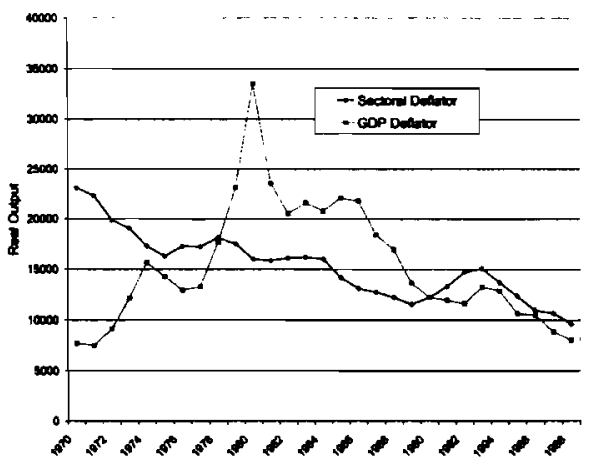

\section{Figure 2 Gold Price in US-Dollar and South African Rand}

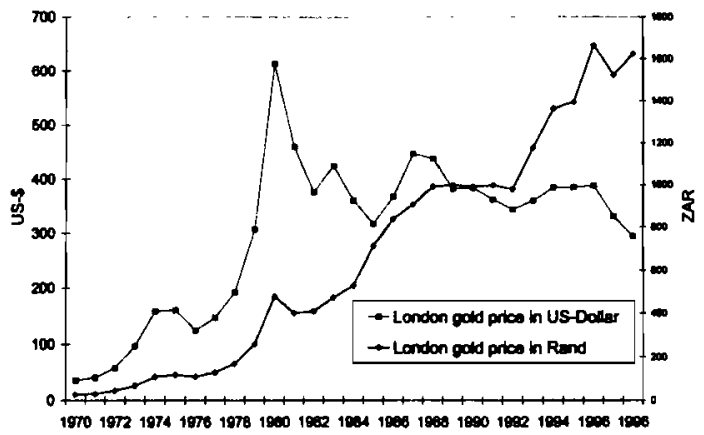

The preceding analysis is based on real value added produced by the three aggregate mining sectors of the economy, computed on the basis of the sectoral GDP deflator. Use of sectoral price deflators does not offer much insight into whether the output of the sector in question has risen in purchasing power 
relative to other sectors in the economy. In order to establish the sensitivity of our results to the use of sectoral price deflators, we also deflate nominal value added by the three principal mining sectors in terms of the aggregate (economywide) GDP-deflator. Only for the Gold and Uranium Mining sector does a significant difference emerge between the two means of deflating. Figure 1 illustrates. ${ }^{8}$ In contrast to the real output series that uses the sectoral GDP deflator for Gold and Uranium Mining, which generates a consistent decline in real output of the sector, the aggregate GDP deflator suggests periods of both expansion and contraction for Gold and Uranium Mining. In terms of the GDP deflator, real output of the sector rose through to the early $1980 \mathrm{~s}$, but has declined ever since. The reason for this lies in the gold price bubble of the early 1980 s - which raised the purchasing power of the sector relative to the rest of the economy. Despite this difference the suggested pattern of development in real output obtained from the two GDP deflators through the course of the 1980 s and 1990s is much the same, with a consistent decline in real output reported in both series, and with both series reporting very similar levels of real output through the course of the 1990s (the correlation coefficient between the two series is +0.71 over this period). The main source of difference between the two output series for Gold and Uranium Mining is thus that the negative growth rate in real output based on the aggregate GDP deflator since 1980 has been more dramatic than the sectoral GDP deflator would imply, with an associated decrease in the purchasing power of gold output in the economy.

Use of the alternative deflators does not change the principal finding of our analysis: that real output of Gold and Uranium Mining has been falling over the 1980-97 period, while that of Coal and Diamond and Other Mining has been rising over the same sample period. For the purposes of the analysis to follow we will employ real output as computed by the sectoral deflator.

The principal finding to emerge from the analysis is that an understanding of the contribution of the mining sector to South Africa's aggregate value added must be sensitive to the differences that arise between the aggregate mining sectors. While the mining sector's contribution to net value added in the economy has declined, this is due to the declining contribution of Gold and Uranium Mining, and not due to developments of the mining sector as a whole? On the other hand, the evidence of a declining contribution of the Gold and Uranium Mining sector to absolute output, and a rising contribution of the Coal and the Diamond and Other Mining sectors, should be tempered by the fact that the gold sector still dominates the total mining sector output. The contribution of Gold and Uranium Mining to total mining output stood at 80.9 per cent in 1970 and, while having declined to 46.5 per cent by 1997 , it still represents the single largest sector in the South African mining industry. 


\subsection{Contribution of the Mining Industry to Total Tax Revenue of the South African State}

In concert with the decline in net output of the mining sector, the contribution to total tax revenues of the mining sector has been declining also.

In Table 3 we illustrate the contribution of revenue from the three aggregate mining sectors as a proportion of total tax revenue of government. The vast majority of tax revenue to emerge from the mining sector is due to gold mining. However, after peaking in the early 1980s (principally due to the gold price peak in the early 1980s), tax revenue from gold mining has declined sharply, and it now contributes only approximately 1 per cent of total government tax revenues.

Table 3 Average proportional contribution to total tax revenues by aggregate mining sector, by decade (Figures are percentages)

\begin{tabular}{|l|c|c|c|}
\hline & $1970 s$ Avg & $1980 s$ Avg & $1990 s$ Avg \\
\hline Coal & 0.29 & 0.52 & N/a \\
\hline Gold and Uranium & 10.02 & 12.51 & 1.13 \\
\hline Diamond and Other & 1.45 & 0.56 & 0.09 \\
\hline
\end{tabular}

\subsection{The Open Economy Context}

The preceding discussion has revealed a declining importance for the mining sector in the aggregate South African economy. In Table 4 we report average annual export earnings by the principal (SIC two digit) sectors of the South African economy. The most dramatic growth in export eamings attaches to the manufacturing sector, particularly during the course of the 1990s. The mining sector nevertheless remains the largest single exporter of the South African economy on average, even during the course of the $1990 \mathrm{~s}^{10}$ 
Table 4 Average annual export earnings per decade by principal economic sectors

\begin{tabular}{|l|c|c|c|}
\hline & 1970s Avg & 1980s Avg & 1990s Avg \\
\hline Agric, Forest and Fish & 533 & 1330 & 4946 \\
& $(6.9)$ & $(3.5)$ & $(4.2)$ \\
\hline Total Mining & 4172 & 23194 & 47724 \\
& $(54.0)$ & $(61.3)$ & $(40.9)$ \\
\hline Total Manufacturing & 1898 & 8914 & 47026 \\
& $(24.6)$ & $(23.6)$ & $(40.3)$ \\
\hline Electricity Gas and Water & 6 & 38 & 139 \\
& $(0.0)$ & $(0.0)$ & $(0.0)$ \\
\hline Building and Construction & 2 & 10 & 28 \\
& $(0.0)$ & $(0.0)$ & $(0.0)$ \\
\hline Services & 11.10 & 4356 & 16720 \\
& $(14.4)$ & $(11.5)$ & $(14.3)$ \\
\hline
\end{tabular}

Note: Figures are in nominal $\mathrm{R}$ Millions, since aggregate deflators for exports are not available. Percentage contributions in brackets.

Table 5 Average annual net export earnings per decade by principal economic sectors

\begin{tabular}{|l|c|c|c|}
\hline & $1970 s$ Avg & 1980s Avg & 1990 s Avg \\
\hline Agric, Forest and Fish & 410 & 693 & 2697 \\
\hline Total Mining & 2971 & 18546 & 38585 \\
\hline Total Manufacturing & -2903 & -13096 & -36857 \\
\hline Electricity Gas and Water & 1 & 35 & 135 \\
\hline Building and Construction & -8 & -15 & -71 \\
\hline Services & 354 & 1397 & 6408 \\
\hline
\end{tabular}

Note: Figures are in $\mathrm{R}$ Millions; positive magnitudes indicate net exports, negative magnitudes net imports.

Similarly, an examination of the net export earnings ${ }^{11}$ of the principal economic sectors of the South African economy further demonstrates that mining has consistently been the largest net eamer of foreign exchange of the economy. By contrast, South Africa has been and remains a large net importer of manufactured goods and services. Table 5 illustrates.

The evidence thus points to the importance of the mining sector as a net exporter and hence earner of foreign exchange in the South African economy. Despite its declining contribution to output in relative and absolute terms mining continues to be a vital component of the economy. Nevertheless, the 
evidence also shows that other sectors, particularly Manufacturing, have shown an increasing capacity to generate forex eamings.

\subsection{Distribution of Output}

Strong changes also emerge in terms of the distribution of the value added produced within the three aggregate mining sectors between the two factors of production employed by the sectors: capital and labour. In order to decompose the value added of the sectors into the earnings of the two factors of production, we graph the real wage bill and net operating surplus (gross operating surplus minus depreciation) as fractions of real GDP over time. Figure 4 reveals a strong upward trend of the wage proportion for the Gold and Uranium Mining sector since the mid-1980s. Also, for Gold and Uranium Mining net operating surplus diminished steadily to a small proportion ( 4 per cent) of real output in 1997. Factor shares for Coal Mining and Diamond and Other Mining remain relatively constant over time, despite some cyclical fluctuation - see Figures 3 and 5.

Only in Gold and Uranium mining has organised labour therefore been successful in appropriating a larger share of value added over time. The associated decrease in the share of value added attaching to equity may go some way toward explaining the declining investment propensity in the Gold and Uranium Mining sector noted elsewhere, ${ }^{12}$ and the increased importance of efficiency improvements in the output growth of the mining sector ${ }^{13}$ Finally, the increased bargaining power of labour in the Gold and Uranium Mining sector and the related real cost increases in labour should serve as a first indicator of likely explanations in employment trends in the sector. We elaborate on this subsequent sections. ${ }^{14}$

As will become clear from a subsequent section, the sharp change in the proportion of net value added paid to labour will come to be strongly correlated with changes in the employment trends of the Gold and Uranium Mining sector.

The proportion of value added that can be explained in terms of the real wage bill and net operating surplus, has declined from over 90 per cent to around 80 per cent for Coal and Diamond and Other Mining, and even lower (71 per cent) for Gold and Uranium Mining. The remainder is attributable to depreciation expenses on the capital stock. Since all three mining sectors have become more capital intensive over the $1970-97$ period, depreciation costs have grown over time.

The evidence suggests that the South African mining sector has been subject to strong change over time, particularly the Gold and Uranium Mining sector. The 
strong change in the distribution of net value added between capital and labour observed in the $1970-97$ period pictures mining as a maturing sector in transition.

Figure 3 Coal mining: Distribution of output between factors of production

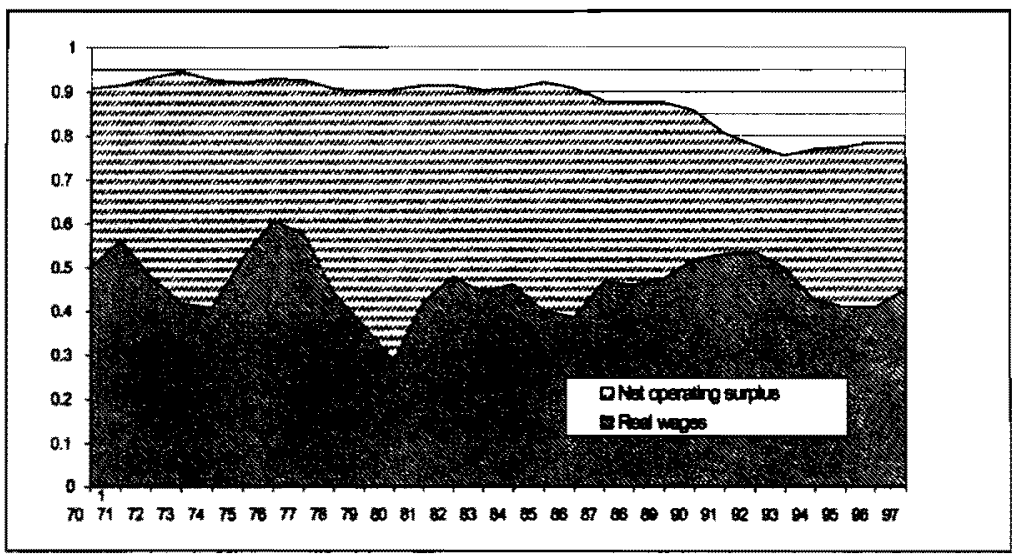

Figure 4 Gold and uranium mining: Distribution of output between factors of production

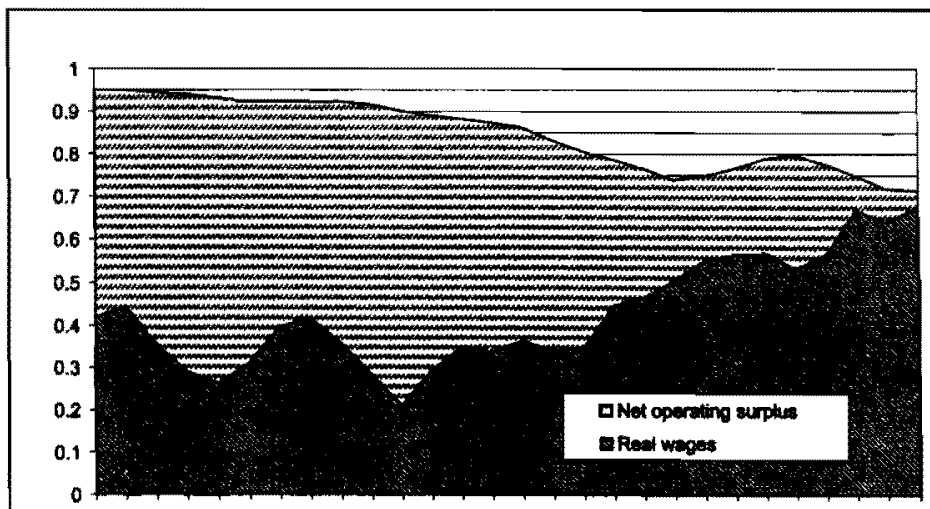

707172737475767787980818283848586878989 s0 91929394959697 
Figure 5 Diamond and other mining: Distribution of output between factors of production

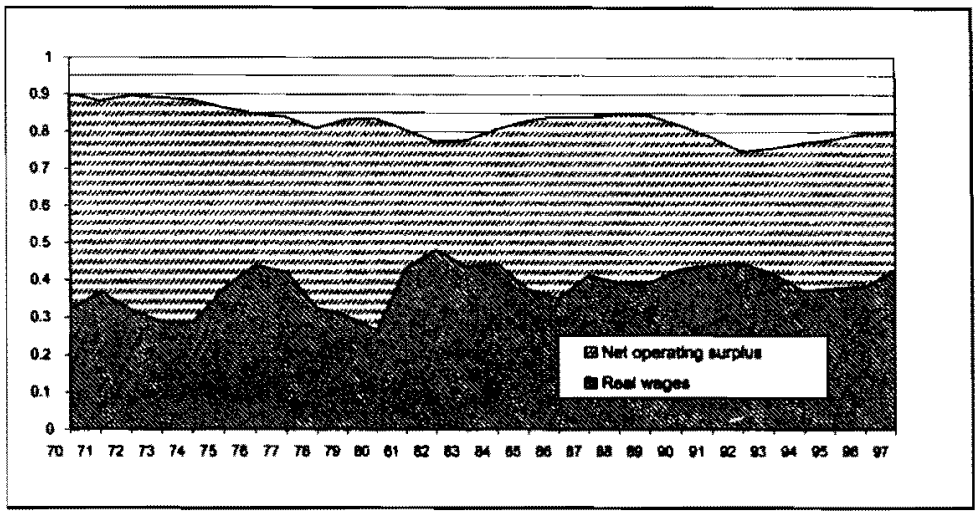

\subsection{Conclusions from the exploratory data analysis}

Our descriptive data analysis suggests the following conclusions. First, the declining importance of mining in the economy has been led by the fall in output of mining's single largest aggregate sector, Gold and Uranium Mining. The two other aggregate mining sectors, Coal Mining and Diamond and Other Mining, have not only increased their shares within the output of the mining sector, but have also marginally expanded their contribution to the aggregate output of the South African economy as a whole. Second, the declining importance of gold mining within the economy is allied to maturation of the sector: the distribution of output between the factors of production, capital and labour has been changing strongly over the course of the 1970-1997 period. From earning less than half of net value added produced by the sector, labour now obtains approximately 67 per cent of the net value added produced in the Gold and Uranium Mining sector. Third, the gold mining sector in particular and the mining sector in general remains a principal earner of foreign exchange in the economy.

These findings suggest that the traditional view of the role of mining in the South African economy is now subject to review. The analyses to be found in some of the standard references to the structure of the South African economy all place emphasis on the significance of mining (see for instance Nattrass, 1981: 129ff and Lipton, 1986). In the case of Nattrass (1981: 148f), the point is also made that the demise of gold mining has often been predicted prematurely. While we do not make so radical a pronouncement, three decades of data, much of which falls outside the time frame considered by the earlier studies, indicates 
that the role of mining has permanently altered. It no longer forms the core of the economy. This role has passed to manufacturing and the service sector, though the mining sector continues to generate significant export earnings. The suggestion is thus that South Africa is engaged in the process of transition from a primary commodity producer, to a more fully differentiated industrialised economy. In this respect it does not differ substantially from other economies, as demonstrated for instance in Grubel and Walker (1989). This conforms to the evidence presented in Fedderke, Henderson, Kayemba, Mariotti and Vaze (2001) and Fedderke and Mariotti (2002) of a structural change in the South African economy, with manufacturing in particular coming to adjust favourably to the removal of historical distortions in the economy.

Finally, the evidence suggests that Gold and Uranium Mining in the economy has now matured in the sense that output growth of the sector is unlikely to be substantial in the future (apparently irrespective of gold price changes), and in the sense that such output growth as does materialise will be driven by total factor productivity gains rather than factor input growth. While similar evidence for other mining sectors is weaker, the evidence also suggests that growth prospects in mining are unlikely to be substantial.

\section{LABOUR MARKET CONDITIONS IN THE THREE AGGREGATE MINING SECTORS OF THE SOUTH AFRICAN ECONOMY}

This section sets out with an examination of trends in labour usage in the three aggregate mining sectors from 1970 to 1997 to provide an initial overview of changes that have occurred in these labour markets. It then turns to possible explanatory factors that might account for the developments in employment levels and concludes with a brief time series (VECM) econometric investigation of the plausibility of such explanations.

\subsection{Employment by the Three Aggregate Mining Sectors of the South African Economy}

Table 6 shows the contribution of South Africa's principal (2-digit SIC code) economic sectors to private sector employment in the economy over time. Again, the service sector's importance as an employer has increased at the expense of the share of primary sectors. The decline in the importance of mining as an employer is not only a relative one. As Table 7 illustrates, absolute employment in all three aggregate mining sectors has fallen dramatically, particularly since the late $1980 \mathrm{~s}$. The decline has been particularly strong during the latter half of the $1990 \mathrm{~s}$, and especially so in Gold and Uranium Mining. 
It is crucial to note that the decline in the relative and absolute contribution of mining to the output of the economy in the $1970 \mathrm{~s}$, from a share of 21.3 per cent to one of 13.3 per cent of private sector GDP in 1980 did not lead to a proportional decline in mining's relative contribution to employment. While the average growth rate in employment across all sectors was 2.2 per cent per annum for this period, mining employment increased by an average 1.9 per cent per annum. As a consequence the relative importance of mining in South Africa's labour markets persisted. This relative buoyancy of the mining sector as an employer, in times of a declining aggregate output performance relative to other sectors, provides the first indication that output alone cannot serve to explain the mining sector's labour usage.

Table 6 Contribution to private sector formal employment by economic sector (Figures are percentages and may not add up due to rounding)

\begin{tabular}{|l|c|c|c|c|c|c|c|}
\hline & 1970 & 1975 & 1980 & 1985 & 1990 & 1995 & 1998 \\
\hline $\begin{array}{l}\text { Agric, Forest and } \\
\text { Fish }\end{array}$ & 19.6 & 16.8 & 15.5 & 13.9 & 13.3 & 13.9 & 14.0 \\
\hline Total Mining & 11.9 & 10.3 & 12.1 & 12.2 & 11.6 & 9.7 & 7.4 \\
\hline Total Manufacturing & 19.1 & 20.9 & 21.5 & 21.6 & 22.5 & 23.1 & 23.1 \\
\hline $\begin{array}{l}\text { Electricity, Gas and } \\
\text { Water }\end{array}$ & 0.8 & 1.0 & 1.2 & 1.4 & 1.4 & 1.2 & 1.2 \\
\hline $\begin{array}{l}\text { Building and } \\
\text { Construction }\end{array}$ & 5.8 & 7.8 & 5.7 & 6.2 & 6.2 & 5.8 & 4.8 \\
\hline Services & 42.8 & 43.3 & 44.0 & 44.8 & 45.0 & 46.3 & 49.5 \\
\hline
\end{tabular}

Table 7 Absolute employment across the three aggregate mining sectors

\begin{tabular}{|l|c|c|c|c|c|c|c|}
\hline & 1970 & 1975 & 1980 & 1985 & 1990 & 1995 & 1997 \\
\hline Coal & 73740 & 76697 & 93082 & 101705 & 89751 & 63260 & 55219 \\
\hline $\begin{array}{l}\text { Gold and } \\
\text { Uranium }\end{array}$ & 425800 & 378167 & 473781 & 526839 & 491100 & 382646 & 241352 \\
\hline $\begin{array}{l}\text { Diamond } \\
\text { and Other }\end{array}$ & 156763 & 171057 & 219800 & 179899 & 199572 & 150732 & 136543 \\
\hline
\end{tabular}

Buoyancy in mining employment relative to other economic sectors persisted through the 1980s and early 1990s. Part of the reason for this is due to the fact that aggregate formal employment in South Africa was declining during the course of the $1990 \mathrm{~s}$, moderating the decline of mining's contribution relative to total employment. Only for the $1995-97$ period have we seen a particularly 
dramatic adjustment in mining's relative contribution to employment: by 1998 the employment share of mining declined to 7.4 per cent.

Further evidence of the partial link between output and employment emerges from the three aggregate mining sectors of the South African economy. Employment in Gold and Uranium Mining rose through the 1970s and early 1980s, peaking in 1986, despite the fact that real output for this sector had been declining since $1970 .{ }^{15}$ Only after 1986 does employment decline steadily and jointly with real output of the sector. Once the employment trend in Gold and Uranium Mining tumed negative, it has remained consistently negative. Even the increase in Gold and Uranium output levels from 1989 to 1993 was not reflected in a reversal of the decline in employment. Thus by 1997 employment in Gold and Uranium Mining had contracted to 60 per cent of the levels attained at its 1986 high point. $^{16}$

Coal Mining historically has shown a relatively strong responsiveness of employment to changes in real output. The high point of employment in the Coal Mining sector corresponded to the peak real output level of 1985. The subsequent decline in real coal output has been accompanied by negative growth in employment. By 1993 real output had fallen by 41 per cent from 1985 (at an average growth rate of -6.14 per cent per annum), employment by 34 per cent (at an average growth rate of -4.82 per cent per annum). This linkage has become somewhat weaker during the course of the 1990s. Although output has been rising strongly since 1993 employment numbers have responded only weakly, and in 1997, employment had fallen again by 3.7 per cent relative to 1996.

The experience of Diamond and Other Mining employment is similar to that of Coal Mining. It demonstrates a relatively close link to output levels prior to the 1990 s, with a much weaker link between output and employment after 1990 . Thus employment and real output for Diamond and Other Mining both peaked around 1980. When employment reached another high in 1991 it had again followed high output levels in the same period. By contrast, the relatively strong growth in output of the Diamond and Other Mining sector since 1992 was not mirrored by positive employment growth. Instead, average employment growth was -1 per cent per annum from 1992-1997.

The following section tums to other possible explanations of employment trends in the mining sector's labour market. 


\subsection{Links between employment and real labour remuneration}

The most immediate additional explanatory variable for employment trends in the mining sector offered by economic theory is the real cost of labour. Figures 6 through 8 depict employment and real remuneration per labourer over time. ${ }^{17}$

We note that with respect to real labour cost, Gold and Uranium Mining is potentially distinct from the other two aggregate mining sectors. It is noticeable that the real cost of labour for the Gold and Uranium Mining sector fell from 1970 through 1986, and rose sharply subsequently. Since employment in the Gold and Uranium Mining sector rose steadily until 1986, and declined subsequently, real labour cost therefore represents a plausible explanatory variable for employment trends in this sector.

For Coal Mining, real labour cost has been on a steady upward trend over time. Employment over the sample period in Coal Mining has both risen (until 1988), and fallen. Sharp increases in real remuneration in 1980-1982 are followed by a levelling off in both real remuneration and employment until 1988. Subsequent rises of real remuneration are associated with declining employment. For Diamond and Other Mining real labour cost has been on a slower but nevertheless steady upward trend, while employment has remained essentially static with some cyclical variation. ${ }^{18}$

Explanations of labour usage patterns are likely to be multivariate in nature, and depend on more than just real labour costs. Nevertheless, an association between real labour cost and employment patterns in the Coal and Diamond and Other Mining sectors appears at best to be somewhat weaker than is plausible for the Gold and Uranium Mining sector. ${ }^{19}$

One possible objection to the evidence presented in the present section is that the patterns observed in the real labour cost variable, for instance for Gold and Uranium Mining do not conform to the conventional wisdom that real wages in the sector rose consistently over the course of the 1970s and the first half of the 1980s. The reason for the discrepancy is readily explained. In computing the real labour cost for the purposes of the present analysis, the nominal wage bill of each of the sectors analysed was deflated by the sectoral GDP deflator. This choice of deflator focuses on the real labour cost to the sector, which makes the appropriate comparison the cost of labour relative to the price of output generated by the sector, rather than the aggregate GDP deflator. While for Coal and Diamond and Other Mining use of the sectoral price deflator or the aggregate GDP deflator makes little substantive difference to the estimated real wage cost, ${ }^{20}$ for Gold and Uranium Mining there is an important difference, as is clear from Figure 9. Real wages computed on the aggregate GDP deflator 
rose over the period through to the mid-1980s, and stabilised subsequently (with a slight decline through the 1990s). However, the aggregate GDP deflator is the appropriate means of deflation only when determining the purchasing power of wages for workers, since their consumption bundle effectively incorporates the output of the economy as a whole. By contrast, in order to determine the real labour cost to an economic sector, the appropriate price adjustment must be made in terms of the price that attaches to the output of that sector, given that the cost of labour is relative to the price obtained for the output the labour produces.

Figure 6 Coal mining: Employment and real cost of labour

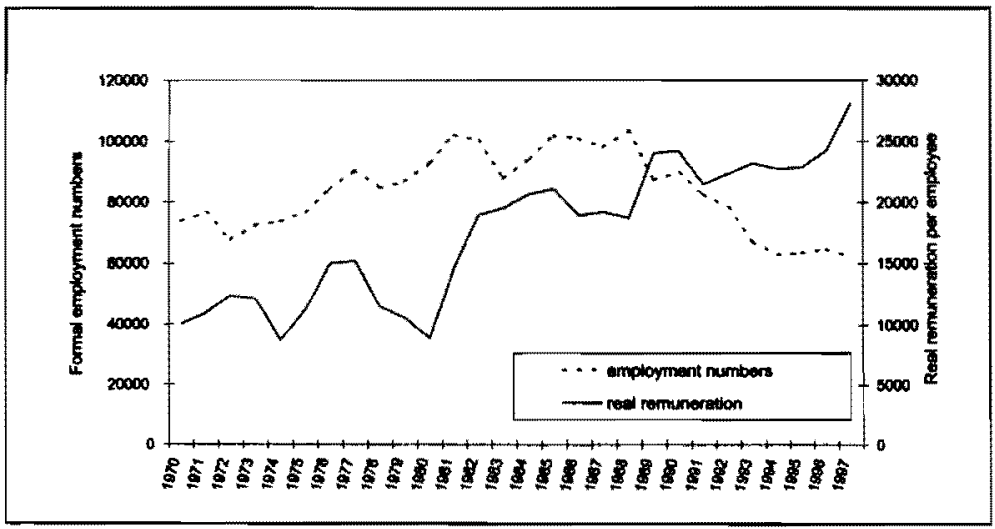

Figure 7 Gold and uranium mining: Employment and real cost of labour

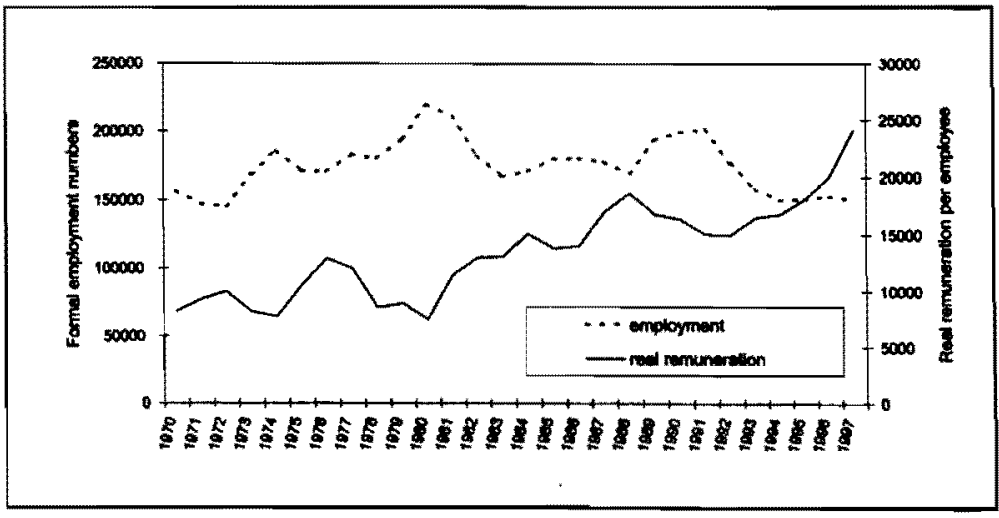


Figure 8 Diamond and other mining: Employment and real cost of labour

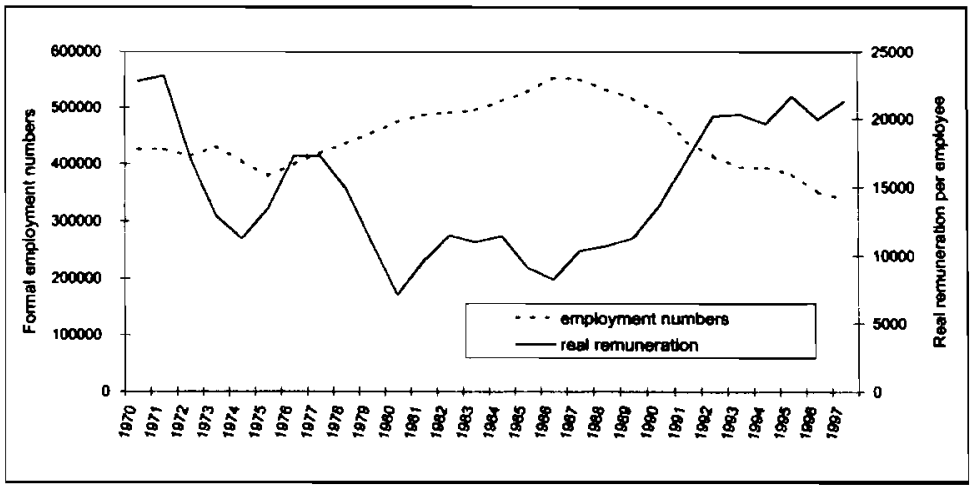

Figure 9 Gold and uranium mining: Comparative real cost of labour using alternative price deflators

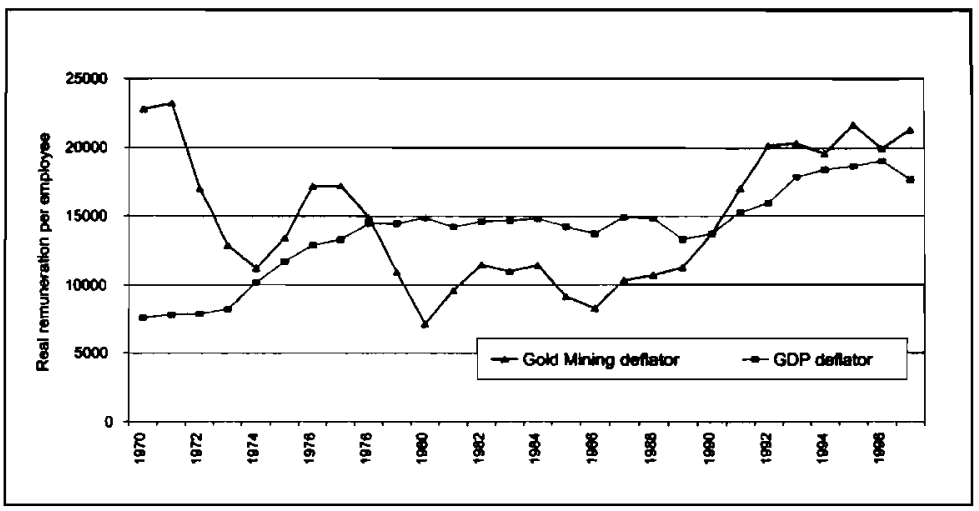

While for the analysis that remains in this section it is thus appropriate to employ the real labour cost series obtained from the sectoral price deflator, the evidence obtained for the Gold and Uranium Mining sector in Figure 9 is nevertheless instructive in a number of respects. The strong decline in real labour cost during the course of the 1970s is due to the rise in the gold price over this period. It follows readily that the bargaining power of labour to increase the real purchasing power of their wages was correspondingly enhanced. Hence the rise in the real wage observed over this period is not surprising. After 1987 the ability of organised labour to raise the real wage has been considerably more constrained. The rising real labour cost appears to have 
translated not only into labour shedding in the Gold and Uranium Mining sector, but it has also appeared to have lowered the return to capital in the sector (recall earlier discussion), and hence at least potentially its growth prospects.

Finally, one should bear in mind that examination of bivariate graphical evidence (or simple correlations) in the current context may prove misleading. Real labour cost is not the only potential explanatory variable that accounts for labour usage. In the present context a rising real labour cost is consistent with rising employment in the labour market, as long as productivity improvements in labour are such that they justify the increasing real labour remuneration. For this reason, we examine patterns in labour productivity in the following subsection. Nevertheless, the exploratory investigation of the present subsection is suggestive of a plausible hypothesis on the mining labour market: that rising real labour cost may have contributed to declining employment in the mining sector. As such, we have a first additional potential explanation besides the declining output trends in the mining sector to account for falling employment in the sector.

Table 8 Average percentage changes in real labour cost in the three aggregate mining sectors

\begin{tabular}{|l|r|r|r|r|r|r|}
\hline & $1970-75$ & $1975-80$ & $1980-85$ & $1985-90$ & $1990-95$ & $1995-97$ \\
\hline Coal & 3.98 & -2.46 & 21.02 & 3.57 & -0.94 & 10.91 \\
\hline $\begin{array}{l}\text { Gold and } \\
\text { Uranium }\end{array}$ & -8.55 & -9.30 & 6.81 & 9.31 & 10.03 & -0.59 \\
\hline $\begin{array}{l}\text { Diamond } \\
\text { and Other }\end{array}$ & 6.61 & -4.88 & 14.70 & 3.98 & 2.17 & 15.58 \\
\hline
\end{tabular}

\subsection{Links between Labour Productivity and Real Labour Cost}

Economic theory would anticipate that perfect labour markets would serve to equalise the marginal product of labour to the marginal cost of labour. It follows that one possible explanation besides changes in the real labour cost for changing employment trends are changes in labour productivity. The theory would predict that at any given real wage rate (marginal cost of labour), a rise in real labour productivity would serve to increase the demand for labour, until the marginal cost - marginal productivity equality is re-established. 
Table 9 Average percentage changes in labour productivity in the three aggregate mining sectors

\begin{tabular}{|l|c|c|c|c|c|c|}
\hline & $1970-75$ & $1975-80$ & $1980-85$ & $1985-90$ & $1990-95$ & $1995-97$ \\
\hline Coal & 3.19 & 7.95 & 11.02 & -1.39 & 4.02 & 5.96 \\
\hline $\begin{array}{l}\text { Gold and } \\
\text { Uranium }\end{array}$ & -4.47 & -4.61 & -4.31 & -1.22 & 6.09 & -1.28 \\
\hline $\begin{array}{l}\text { Diamond and } \\
\text { Other }\end{array}$ & 2.40 & 0.58 & 5.64 & 1.19 & 5.11 & 8.58 \\
\hline
\end{tabular}

The implication of the evidence contained in Tables 8 and 9 is that for all sectors the real labour cost variable varies positively with real labour productivity. The correlation between the two variables in fact confirms the association: for Coal Mining +0.75 , Gold and Uranium Mining +0.41 , Diamond and Other Mining +0.86. However, it is noticeable that the correlation for Gold and Uranium Mining is weaker than in the other two sectors.

Several explanations are possible for the apparently weaker correlation found for Gold and Uranium Mining. First, higher union pressure might have hindered real wages from falling in the presence of falling productivity or even raised real wages. We have already seen that the proportion of value added allocated to wages in the Gold and Uranium Mining sector declined from 42 per cent in 1970 (with lows of 21 per cent) and stabilised at around 35 per cent of the real output value (GDP) until 1986. It increased thereafter to 67 per cent in 1997. By contrast, no corresponding increase in the share of output flowing to labour is evident for the other two aggregate mining sectors. The suggestion might be that for Gold and Uranium Mining real wage pressure was greater than the increases merited by labour productivity improvements.

If correct, the consequence of this finding would be that the declining levels of employment in Gold and Uranium Mining may be due to excessive real wage pressure in the sector, which outstripped real productivity increases.

An alternative explanation refers to the nature of subterraneous gold mining itself. The increasing difficulty of gold ore extraction may have led to a falling labour productivity by virtue of the constraints imposed by the mining tasks at hand. As Figure 10 illustrates, gold mines increased the ore milled steadily after 1978 while kilograms (fine) produced decreased over the same period. ${ }^{21}$ This loss of efficacy is reflected in falling grades in terms of grams per ore milled. ${ }^{22}$

Here the explanation for declining labour usage would lie not in excessive wage pressure, but in the technological requirements of more extreme mining conditions. If correct, this explanation implies a rising output per worker in the 
face of falling employment. However, the correlation between labour productivity and employment numbers while negative is not strong. For Coal Mining the coefficient is -0.10 , for Gold and Uranium Mining -0.42 and for Diamond and Other Mining: -0.19 . This suggests that labour shedding has played a limited role in the rise of productivity, except perhaps for the Gold and Uranium Mining sector.

Figure 10 Gold Mining: Ore milled and production volumes (Quarterly)

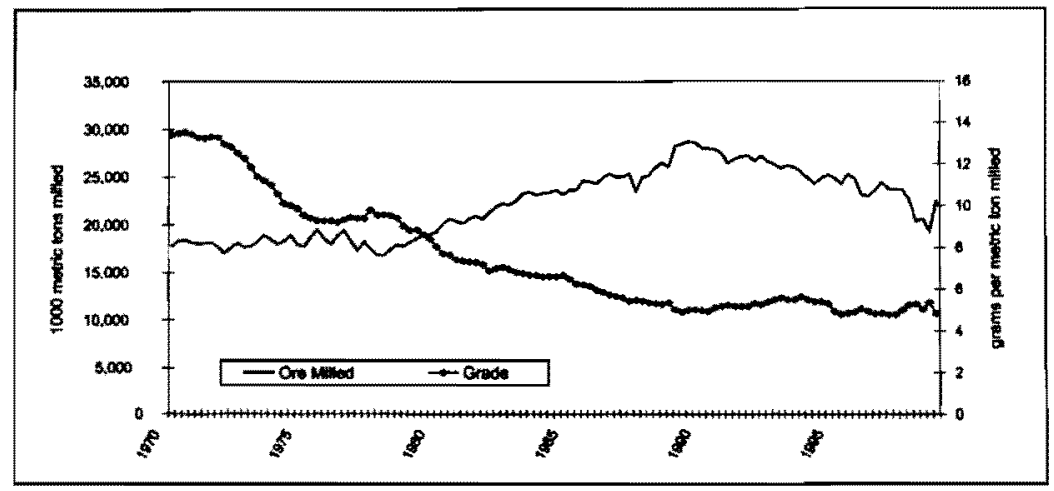

There are additional considerations that suggest that excessive wage pressure is associated with falling employment levels in the mining sector. It is possible to identify structural breaks in two of the aggregate mining sectors that illustrate the importance of the growth in real wage costs relative to labour productivity:

- For Coal Mining it is possible to identify such a break around 1986. Average annual growth in productivity was 6.57 per cent for Coal Mining from 1970-1986, just above real labour cost growth of 6.4 per cent. From 1987-1997, average real labour cost growth was 4.12 per cent per annum but productivity growth now stood at only 2.91 per cent. The decline in employment in the Coal Mining sector after 1987 is thus not surprising. Real labour productivity ceased to justify the rate of real wage increase of the sector, and demand for labour fell correspondingly.

- For Gold and Uranium Mining real labour cost decreased on average by 4.05 per cent per annum from 1970 to 1986 and increased by 9.55 per cent per annum form 1987-1997. Average productivity growth per annum was negative at -4.93 per cent from $1970-1986$ and positive at 3.01 per cent from 1987-1997. The figures manifest an increasing gap between the growth rates of real wages and productivity. If we recall that in this period real output levels were decreasing in the Coal and Gold and Uranium Mining sectors, ${ }^{23}$ and employment levels were at their peak, the 
subsequent labour shedding appears inevitable. The rift between real wage increases and increases in real labour productivity constituted a strong disincentive to employ labour post 1986, and demand for labour fell correspondingly. ${ }^{24}$

By contrast, for Diamond and Other Mining there is much weaker evidence of a structural break in its labour market. Average real labour cost growth for Diamond and Other Mining stood at 5.21 per cent from 1970 to 1986 and 5.52 per cent from 1987 to 1997 . This steady growth rate is mirrored by average annual productivity increases of 3.21 per cent and 3.67 per cent respectively for the two periods. Thus real wage growth consistently outstripped the growth in labour productivity, and changes in employment patterns in this sector is thus difficult to associate with a change in the relation between real wage growth and real labour productivity.

We provide one final consideration. We have seen that relative changes in real wages and productivity provide a plausible explanation of labour shedding in the South African mining sector. However, one reason for the rising wage bill of the mining sector might be that the labour force of the mining sector has shown dramatically improved skills levels. This would explain rising real wages, while being consistent with either constant or rising levels of employment. We might also expect a changing skills composition to affect the average productivity of labour.

Data on the skills composition of the labour force is available only for Coal Mining and Gold and Uranium Mining. ${ }^{25}$ The data provides information on the number of employees that fall into the categories denoted "skilled" and "unskilled". On the basis of this we define the skills ratio as the proportion of the labour force that is considered to be skilled. Figures 11 and 12 display changes in the two aggregate mining sectors' labour force in terms of skills composition. Both sectors show an improvement in the skills composition of the labour force from the mid-1980s. However, we note that the rising average skills level in the two mining sectors' work force is not due to a substantial increase in the number of skilled workers. Instead, it is due to a shedding of unskilled workers.

The evidence of the present section is thus more consistent with an interpretation that suggests that the rising real wage in mining sectors has led to labour shedding, and an effort on the part of mining to increase average labour productivity in order to justify the higher wage structure. It is difficult to suggest that the changing skills composition of the labour force is responsible for the rise in real wages. 
Figure 11 Coal mining: Skills composition of labour force

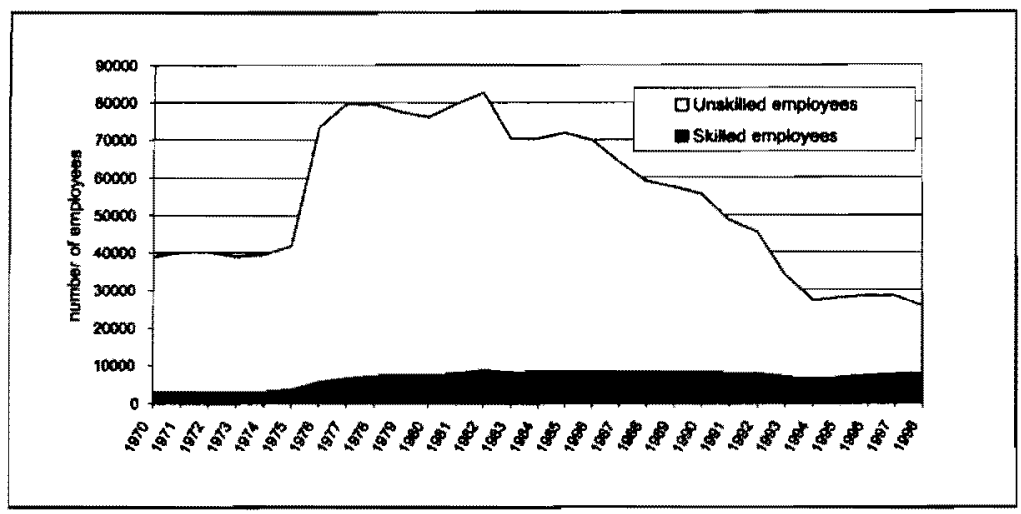

Figure 12 Gold mining: Skills composition of labour force

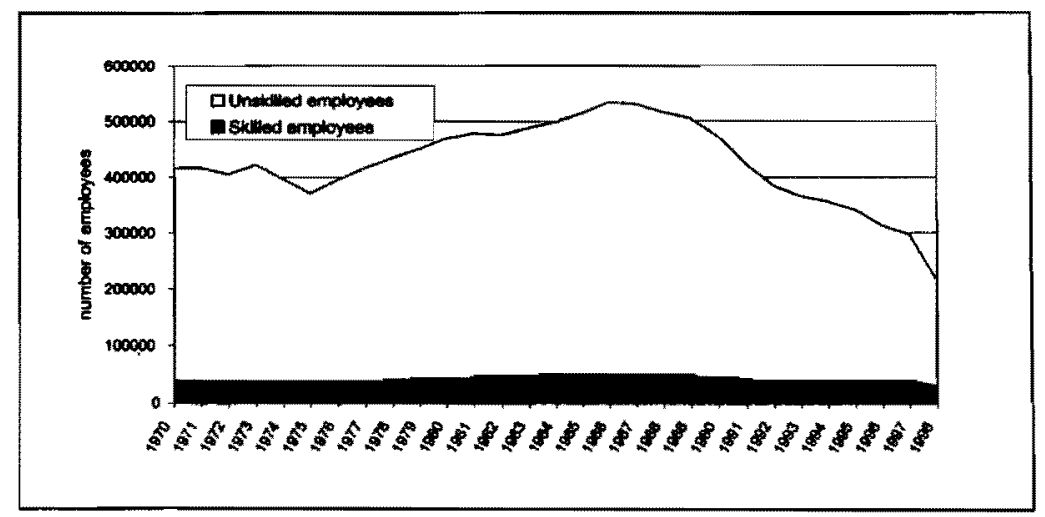

\subsection{Conclusions from the Exploratory Data Analysis}

The descriptive analysis above has presented developments in employment trends, in real labour cost, in labour productivity, and examined potential links between these dimensions of the labour market. The most immediate cause of declining employment in mining is declining output of mining, and in Gold and Uranium Mining in particular. However, examination of the evidence suggests that at best output levels of the South African mining sectors are a partial explanation of declining employment trends. 
Two further possible explanations for employment trends in South Africa's mining sectors were therefore examined: real labour cost and real labour productivity. Exploratory examination of the evidence suggests that real labour cost for all three mining sectors demonstrates the negative correlation with employment that economic theory would predict. Moreover, increases in real labour productivity have not been sufficient to warrant the increases in real labour cost observed for the mining sectors, nor have they been justified by increased employment of skilled labour. Our findings suggest that output trends, use of capital stock, and real labour cost all contribute toward an explanation of labour usage patterns in the three aggregate mining sectors. What differs between the three sectors is not the explanatory variables, but the responsiveness of labour usage to change particularly in output, and in real labour costs. Changes in real labour cost are expected to have the strongest impact on Diamond and Other Mining, followed by Gold and Uranium and Coal Mining. Diamond and Other Mining also shows the strongest responsiveness to changes in output levels, followed by Coal and Gold and Uranium Mining.

The exploratory data analysis presented above cannot be conclusive on its own. In the final part of the labour market discussion, we therefore employ time series estimation in order to examine the relative importance of the alternative explanatory variables identified in the initial exploratory data analysis in accounting for employment trends in the three mining sectors individually.

\subsection{An Econometric Exploration of some Reasons for the Decline in Mining Employment}

In what follows we undertake a more detailed econometric exploration of the hypotheses advanced above in explanation of the mining sector's employment patterns.

We begin our discussion with a brief introduction to the econometric methodology employed for the study, before moving on to a discussion of the more detailed results obtained. Johansen ${ }^{26}$ techniques of estimation employ a vector error-correction (VECM) framework, for which in the case of a set of $k$ variables, we may have cointegrating relationships denoted $r$ such that $0 \leq r \leq k-1$. This gives us a $k$-dimensional vector autoregression (VAR):

$z_{i}=A_{i} z_{i-1}+\cdots+A_{m} z_{i-m}+\mu+\delta_{i}$

where $\boldsymbol{m}$ denotes lag length, and $\delta$ a Gaussian error term. While in general $z_{1}$ may contain $I(0)$ elements, as long as non-stationary variables are present as in the present case, we are exclusively restricted to $I$ (1) elements. Reparametrisation provides the VECM specification: 


$$
\Delta z_{1}=\sum_{t=1}^{k-1} \Gamma_{i} \Delta z_{t-1}+\Pi z_{t-k-1}+\mu+\delta
$$

The existence of $r$ cointegrating relationships amounts to the hypothesis that:

$$
H_{1}(r): \Pi=\alpha \beta
$$

where $\Pi$ is $p \times p$ and $a, \beta$ are $p \times r$ matrices of full rank. $H_{l}(r)$ is thus the hypothesis of reduced rank of $\Pi$. Where $r>1$, issues of identification arise. ${ }^{27}$

The question we confront in our econometric investigation is whether changing employment patterns in South Africa's mining sectors bear any relation to changes in the real wage and changes in the demand for output of the mining sectors. One means of answering this question is to consider a labour requirements equation, derived from the inversion of the production function of each mining sector. Assuming that technology is Cobb-Douglas, logtransforming and inverting a standard production function we obtain:

$$
\ln L=\alpha+\beta \ln \mathrm{Y}+\delta \ln \mathrm{K}+\lambda \ln \left(\frac{W}{P}\right)+\varepsilon_{i}
$$

where $Y$ denotes output, $K$ the capital stock, $L$ the labour input into production, $\forall$ other factors influencing output such as technological progress and real factor prices, $\frac{W}{P}$ real per labourer remuneration, and $\varepsilon$ a standard error term.

Our particular interest lies in two parameters. We wish to know whether changing output levels impact on the demand for labour by the mining sectors in the economy. Specifically, we wish to know whether $\beta>0$, and hence whether declining output levels in mining explain the labour shedding of these sectors. Second, we wish to know whether changing levels of the real wage influences the demand for labour. Given the preceding discussion on the labour market for the three mining sectors, we are particularly interested to establish whether $\lambda<0$ and hence whether changing real wage patterns in the mining sectors have been a source of the labour-shedding that we have already reported on.

Lastly, we note that the specification above allows us to establish the impact of changing capital intensity in the mining sector on the demand for labour. The sign of $\delta$ allows for a determination of whether the factors of production act as complements or substitutes in the three aggregate mining sectors of the South African economy.

For all three aggregate mining sectors, examination of the inverted production function specified by the labour requirements equation confirms the presence of a single cointegrating vector and hence equilibrium relationship. The resulting 
coefficients on the explanatory variables in the long run cointegrating relationships are reported in Table 10. Examination of the error correction equation confirms that each of the labour requirement equations estimated for the three mining sectors is an equilibrium model, in the sense that the negative and significant error correction term allows for the elimination of any deviation between actual and equilibrium labour usage. The error correction (ECM) parameters, which can be interpreted as the proportion of any error between actual labour usage and the labour usage implied by the equilibrium relationship that would be eliminated in the succeeding time period, are also reported in Table $10^{28}$

For Coal Mining and Diamond and Other Mining, the output coefficients suggest that growth in output is not jobless once other potential explanatory variables of labour usage are controlled for. On the contrary, growth in Coal Mining output appears to generate an almost proportional increase in the demand for labour, and growth in Diamond and Other Mining appears to generate a strong increase in the demand for labour. For Gold and Uranium Mining the impact of output on labour demand is lower than in the other two aggregate mining sectors in the economy, and proves statistically insignificant. Hence, for the one sector in which the exploratory data analysis showed that declining output levels could potentially have accounted for declining labour demand, the statistical evidence fails to corroborate a clear link. We also note that the relative responsiveness of the three sectors to output conforms to the priors to have emerged from our exploratory data analysis.

Table 10 Long-run cointegrating vectors

\begin{tabular}{|l|c|c|c|c|c|}
\hline & $\operatorname{lnY}$ & $\operatorname{lnK}$ & $\ln \frac{W}{P}$ & ECM & SE \\
\hline Coal Mining & $\frac{0.90^{*}}{[37.36]}$ & $\frac{-0.19^{*}}{[11.35]}$ & $\frac{-0.44^{*}}{[12.17]}$ & $\frac{-0.55^{*}}{(2.98)}$ & 0.19 \\
\hline $\begin{array}{l}\text { Gold and } \\
\text { Uranium Mining }\end{array}$ & $\frac{-0.31}{[1.74]}$ & $\frac{-0.16}{[2.10]}$ & $\frac{-0.69^{*}}{[13.24]}$ & $\frac{-1.1^{*}}{(3.03)}$ & 0.36 \\
\hline $\begin{array}{l}\text { Diamond and } \\
\text { Other Mining }\end{array}$ & $2.26^{*}$ & $\frac{-0.26}{[9.71]}$ & $\frac{-1.45^{*}}{[0.79]}$ & $\frac{-0.63^{*}}{[8.25]}$ & 0.22 \\
\hline
\end{tabular}

Note: Figures in round brackets denote $t$-statistics; figures in square brackets denote chi-square statistics at one degree of freedom on overidentifying restrictions on the cointegrating space for significance; * denotes statistical significance.

On the other hand, it appears as if capital has displaced the use of labour in both the Coal and the Diamond and Other Mining sectors, though the elasticity of labour with respect to capital is relatively modest. By contrast, changing usage 
of capital seems to have had very little impact on labour usage in the Gold and Uranium Mining sector.

In all three aggregate mining sectors rising real per labourer remuneration is consistently and strongly related to declining labour usage. Each percentage point increase in the real per labourer remuneration of the sector has depressed labour usage by almost half a per cent in Coal Mining, almost 0.7 per cent in Gold and Uranium Mining and by 1.45 per cent in Diamond and Other Mining. Again, Diamond and Other Mining is the most responsive of the three aggregate mining sectors to changes in real labour remuneration. Again moreover, the econometric analysis confirms the predicted relative responsiveness to real wage changes that emerged from the exploratory data analysis. ${ }^{29}$

The conclusions to have emerged from the exploratory data analysis concerning the negative real wage elasticity is thus confirmed. ${ }^{30}$

\section{CONCLUSIONS}

The story of the mining sector in South Africa over the last three decades of the twentieth century is one of structural change. We saw strong declines in the sector's contribution to value added in the economy, principally due to the decline in the production of Gold and Uranium Mining. The distribution of output of the Gold and Uranium Mining sector shifted substantially away from equity to labour earnings - through sharp increases in real wages.

The contribution of mining to the net value added produced in the economy has declined sharply since 1970 . This decline is attributable primarily to the declining contribution of Gold and Uranium Mining to the total net value added produced in the economy. By contrast, the other two aggregate mining sectors of the economy, Coal Mining and Diamond and Other Mining have contributed a relatively constant proportion to aggregate net value added. A more disaggregated investigation of output by individual mining sectors confirms the view that a number of sectors demonstrate a growing contribution to output, and that it is chiefly the contribution of gold mining to value added in the economy that has been in decline.

The decline in the net value added contributed by mining is mirrored in a declining contribution of mining to total tax revenues of the state. Again, it is gold mining whose contribution has been most clearly in decline since the early 1980s. 
The mining sector, and gold mining in particular, remains crucial in terms of the foreign exchange earnings of the economy, however. While the manufacturing sector has come to generate greater export sales than mining during the course of the 1990s, as a net exporter the mining sector remains the single most important earner of foreign exchange for the economy.

Finally, the distribution of the net value added produced by the Gold and Uranium Mining sector of the economy has changed fundamentally over the 1970-97 period. Whereas labour earned less than half of the value added in 1970 , by the end of the 1990 s labour earned approximately 67 per cent of net value added in the sector. As such, the distribution of output within the sector has undergone a fundamental transition, and one that is far more dramatic than in the remaining two aggregate mining sectors of the economy. Certainly it points to a mining sector in transition, assuming a different role to its traditional one in contributing to the net output of the South African economy.

In terms of the contribution of the mining sector to employment in the economy, our findings mirror those we obtain for the contribution of mining to net value added in the economy. In particular, mining has contributed a steadily shrinking proportion toward total employment in the economy, and the 1990s have seen a very dramatic absolute fall in employment of particularly unskilled workers. The decline in the importance of mining as an employer is less severe than the decline in its contribution to value added in the economy. And again, the decline is mainly attributable to a massive loss of employment in Gold and Uranium Mining as the largest employer in the mining sector as a whole, although proportionally the employment decrease in Coal Mining has been equally sharp. The weakest proportional decrease has occurred in Diamond and Other Mining. Our analysis explores some of the potential reasons for the decline in employment in the three aggregate mining sectors. Time series (cointegration) data analysis confirms that employment losses in the mining sector is substantially attributable to rising real wage costs. This finding remains robust even where we control for the skills composition of the labour force.

South Africa's economic development has been intimately tied to growth in its mining sector. The evidence presented in the present paper has suggested that this trajectory has been subject to structural change - with a move away from primary commodities production to manufacturing and service industry as sources of further growth for the economy. 


\section{ENDNOTES}

1 We thank an anonymous referee for useful comments on an earlier draft of this paper. The Trade and Industry Policy Strategies kindly provided some of the data for the present study. Responsibility for the contents of the paper rests with us alone. An earlier version of the paper contains a wider discussion of additional data series. The Econometric Research Southern Africa Policy Paper No. 9 version of this paper is available at www.wits.ac.za/economics/ersa.

2 See Loots (1998), IDC (1998), Jones and Muller (1992).

3 Historically the investment rate of the mining sector was of significance to the aggregate economy, with output growth in the sector being driven primarily through capital accumulation. The 1980's and 1990's have seen a steady shift in output growth away from capital accumulation to growth that is driven by growth in total factor productivity (see Fedderke, 2002). Thus investment by the mining sector has assumed less significance in the economy over time.

4 Focus on the three aggregate mining sectors is due to data convenience. It is for these three-digit SIC sub-sectors that consistent time series data is available. Where more detailed data was available we note any additional information of relevance.

5 In the discussion that is to follow, we consider the term output to mean value added, rather than gross output or sales. Ignoring intermediate inputs of course gives no indication of the magnitude of derived demand associated with mining. Consideration of derived demand effects lies beyond the scope of this paper.

6 Note that Platinum is included in Diamond and Other Mining throughout.

7 The first point to note concerning this evidence is that it proves to be consistent with the evidence that emerges from an examination of the physical volume of output of the eight principal mining industries of the South African economy. Gold mining was distinguished from other mining sectors by virtue of its strong and sustained decline in output in volume terms, while other sectors either increased their volume of output, maintained constant levels of physical output, or where they did report declining output, showed greater cyclical variation.

8 Figures for Coal and Diamond and Other Mining are available in the Econometric Research Southern Africa Policy Paper No. 9 version of this paper. See www.wits.ac.za/economics/ersa.

9 Examination of more disaggregated data provided by the Minerals Bureau on the performance of the eight principal mining sectors confirms the point: among these, Coal, Platinum Group Metals, Iron Ore, Manganese Ore and Aggregate and Sands and can be characterised as growing. Apart from Gold; only Chromite and Copper decline in their 
value of total sales. Care should be taken in interpreting these figures, however. Total sales at this level of disaggregation are reported in nominal terms, and sectoral price deflators were not available. Hence reliable indicators of real output were not available.

10 The manufacturing sector has begun to export more than the mining sector since 1995 in absolute terms.

11 Defined as the difference of the exports and imports of the output generated by a sector. Thus, the net export measure does not capture the imports of intermediate goods employed by a sector in production. The consequence in the current context will be to bias upward the net export performance of mining, since South Africa imports little by way of primary commodities, while they may have a relatively strong reliance on capital and manufactured imports, for instance. Unfortunately we were unable to locate the data necessary to establish the net foreign exchange earnings of the mining sectors.

12 See for instance Fedderke et al. (2001).

13 See the discussion in Fedderke (2002).

14 And see also the discussion in Fedderke and Mariotti (2002).

15 The returns to production in a sector are properly understood in terms of the price obtained for the output of that sector - hence the use of the sectoral price deflator. Once the post-1985 evidence for Gold and Uranium Mining and the evidence from the other two aggregate mining sectors is considered, it is difficult to persist with the notion that output is a principal driver of labour usage in this sector.

16 The Gold and Uranium Mining sector remains the fifth largest employer in the economy in absolute terms, though it also has the fifth lowest employment growth rate amongst all sectors (and is amongst the sectors with the strongest proportional decrease in employment).

17 We define real remuneration per labourer as: Real Wage Bill/Employment. As the nominal wage bill of each of the sectors was deflated by the sectoral GDP deflator to obtain the real wage bill, it is the real cost of labour relative to the price of output generated by the sector that we are discussing with regard to employment patterns.

18 One should take care in interpreting this evidence. Closer examination of the two series shows that there is at least some countercyclical variation in employment and the real labour cost. Once other explanatory variables are controlled for, we might therefore find that the link between real labour cost and employment for the Diamond and Other Mining sector might increase in strength.

19 Correlation coefficients bear out the plausibility of a stronger association between real labour cost and employment in the Gold and Uranium Mining sector than in the remaining two aggregate mining sectors. Gold and Uranium Ore Mining exhibits an employment-real labour cost 
correlation of -0.81 , Diamond and Other Mining -0.41 and Coal Mining 0.24 . All sectors manifest the negative correlation we would expect.

20 Full results are available in are available in the Econometric Research Southern Africa Policy Paper No. 9 version of this paper. See www.wits.ac.za/economics/ersa.

21 See also Mainardi (1999).

22 Additional evidence on grades is available in the Econometric Research Southem Africa Policy Paper No. 9 version of this paper. See www.wits.ac.za/economics/ersa.

23 In the Diamond and Other Mining sector the decrease in output set in only after 1989 .

24 Given the importance of Gold and Uranium mining as an employer in the economy, this serves as an important insight into the poor employment creation in the economy as a whole over this period.

25 This data is available only for members of the Chamber of Mines. An important note of caution on the compatibility of data at our disposal has to be made at this stage. We derive our conclusions on the skills ratio in the two sectors above, Coal and Gold and Uranium Mining, from data provided by the Chamber of Mines. The remainder of data used in this section has been drawn from WEFA Southern Africa. The Gold Mining data by and large corresponds to the aggregate Gold and Uranium Mining sector in the WEFA dataset in regard to employment numbers and nominal eamings given. For Coal Mining we find a more substantial discrepancy in the number of employees and therefore in total nominal earnings reported. Differences in the nominal earnings are not proportional to the difference in the employment figure. Calculations based on the Chamber of Mines data would lead to a higher average nominal remuneration per employee (skilled and unskilled) for most of the years 1970-1997.

26 See Johansen (1991) and Johansen and Juselius (1990).

27 See Wickens (1996), Johansen and Juselius (1990, 1992), Pesaran and Shin (1995a, 1995b), Pesaran, Shin and Smith (1996).

28 Detailed results on the trace and maximal eigenvalue statistics specifying the reduced rank of the stochastic matrix, and on the full error correction specification are available from the authors.

29 We have already seen that the skills composition of the labour force is unlikely to modify the finding of a negative wage elasticity. This is further confirmed by the fact that when we control for the skills ratio in the labour requirements equation already estimated, we continue to find a unique cointegrating vector, and the real wage elasticity remains negative. Where we estimate a labour requirements equation for the skilled and unskilled workforce separately, we again obtain unique cointegrating vectors for the two sections of the workforce for both 
mining sectors. For Coal Mining, the estimated elasticities are quite distinct. For the skilled workforce there is a positive association between skilled labour usage and skilled real per labourer remuneration. By contrast, for unskilled labour, there exists a powerful negative association between unskilled labour usage and unskilled real per labourer remuneration. For Gold and Uranium Mining the estimated elasticities for both the skilled and the unskilled workforce demonstrate a negative association between labour usage and real per labourer remuneration.

30 One concern with the present set of estimations is that the sample size available for the VECM ( 28 observations) attenuates statistical power. We therefore repeated our estimation using dynamic heterogenous panel estimation on all three panels. All results prove to be consistent with the findings reported here. 


\section{APPENDLX}

\begin{tabular}{|c|c|c|}
\hline Section & Source & Variables Used \\
\hline $\begin{array}{l}\text { Production Volumes } \\
\text { In the Mining Sector }\end{array}$ & $\begin{array}{l}\text { Minerals } \\
\text { Bureau }\end{array}$ & $\begin{array}{l}\text { Total Production } \\
\text { (Diamonds),Production, Mass of } \\
\text { Total Sales where Production not } \\
\text { available }\end{array}$ \\
\hline \multirow{2}{*}{$\begin{array}{l}\text { The Importance of Mining } \\
\text { in terms } \\
\text { Of its contribution to Value } \\
\text { Added in the South African } \\
\text { Economy }\end{array}$} & WEFA & $\begin{array}{l}\text { GDP, by sector } \\
\text { Real GDP }\end{array}$ \\
\hline & $\begin{array}{l}\text { WEFA } \\
\text { (SARB } \\
\text { Quarterly } \\
\text { Bulletin) }\end{array}$ & $\begin{array}{l}\text { London Gold Price in US-Dollar } \\
\text { London Gold Price in ZAR }\end{array}$ \\
\hline $\begin{array}{l}\text { Contribution of the Mining } \\
\text { Industry to Total Tax } \\
\text { Revenue of the South } \\
\text { African State }\end{array}$ & $\begin{array}{l}\text { WEFA } \\
\text { (CSS) }\end{array}$ & $\begin{array}{l}\text { Mining taxation by aggregate mining } \\
\text { sector }\end{array}$ \\
\hline \multirow[t]{2}{*}{$\begin{array}{l}\text { Aggregate Labour Market } \\
\text { Conditions in the } \\
\text { Three aggregate mining } \\
\text { sectors of the South African } \\
\text { Economy }\end{array}$} & WEFA & $\begin{array}{l}\text { Formal Employment (number) } \\
\text { Nominal Labour remuneration } \\
\text { (current Prices) } \\
\text { GDP (constant prices) } \\
\text { GDP deflator (index, 1990=100) }\end{array}$ \\
\hline & $\begin{array}{l}\text { Chamber } \\
\text { of Mines }\end{array}$ & $\begin{array}{l}\text { Skilled Employees, Average No. in } \\
\text { Service } \\
\text { Unskilled Employees, Average No. } \\
\text { in Service } \\
\text { For Coal and Gold Mines } \\
\text { Members of the Chamber of Mines }\end{array}$ \\
\hline $\begin{array}{l}\text { Links between Labour } \\
\text { Productivity and Real } \\
\text { Labour Cost }\end{array}$ & $\begin{array}{l}\text { Chamber } \\
\text { of Mines }\end{array}$ & $\begin{array}{l}\text { Metric tons ore milled Production } \\
\text { total kilograms fine Production grade } \\
\text { (grams per metric ton milled) }\end{array}$ \\
\hline
\end{tabular}




\section{REFERENCES}

1 FEDDERKE, J.W. (2002) "The Contribution of Growth in Total Factor Productivity to Growth in South Africa: 1970-97", forthcoming South African Journal of Economics, Econometric Research Southern Africa Policy Paper No. 16, University of the Witwatersrand.

2 FEDDERKE, J.W., HENDERSON, S., KAYEMBA, J., MARIOTTI, M., \& VAZE, P. (2001) "Changing Factor Market Conditions in South Africa: The Capital Market - A Sectoral Description of the Period 19701997", Development Southern Africa, 18(4): 493-512, Econometric Research Southern Africa Policy Paper No. 7, University of the Witwatersrand.

3 FEDDERKE, J.W. \& MARIOTTI, M. (2002) “Changing Factor Market Conditions in South Africa: The Labour Market - A Sectoral Description of the Period 1970-1997", Mimeo, and see also Econometric Research Southern Africa Policy Paper No. 5, University of the Witwatersrand.

4 GRUBEL, H.G. \& WALKER, M.A. (1989) Service Industry Growth: Causes and Effects, Vancouver: The Fraser Institute.

5 INDUSTRIAL DEVELOPMENT CORPORATION and DEPARTMENT OF TRADE AND INDUSTRY (1998) Sectoral Prospects: Growth Guidelines for South Africa's 80 Industries - 1997-2001.

6 JOHANSEN, S. (1991) "Estimation and Hypothesis Testing of Cointegration Vectors in Gaussian Vector Autoregressive Models," Econometrica, 59(6): 1551-80.

7 JOHANSEN, S., \& JUSELIUS, K. (1990) "Maximum Likelihood Estimation and Inference on Cointegration - with Applications to the Demand for Money" Oxford Bulletin of Economics and Statistics, 52(2): 169-210.

8 JOHANSEN, S., \& JUSELIUS, K. (1992) "Testing structural hypotheses in a multivariate cointegrating analysis of the PPP and the UIP for UK," Journal of Econometrics, 53: 211-44.

9 JONES, S., \& MULLER, A. (1992) The South African Economy 19101990, London: Macmillan.

10 LIPTON, M. (1986) "The Interests of Mining Capital," in: Lipton, M., 1986, Capitalism and Apartheid, South Africa 1910-1986, Wildwood House, Hants.

11 LOOTS, E. (1998) "Job Creation and Economic Growth," South African Journal of Economics, 66(3): 319-36.

12 MAINARDI, S. (1999) "Geological Occurrence and Economic Feasibility in Closing Decisions by Gold Mines," South African Journal of Economic and Management Sciences, 2(2): 240-57.

13 NATTRASS, J. (1981) The South African Economy: its Growth and Change, Cape Town: Oxford University Press. 
14 PESARAN, M.H. \& SHIN, Y. (1995a) "Long Run Structural Modelling" Unpublished manuscript, University of Cambridge.

15 PESARAN, M.H. \& SHIN, Y. (1995b) "An Autoregressive Distributed Lag Modelling Approach to Cointegration Analysis" DAE Working Paper No.9514, Department of Applied Economics, University of Cambridge.

16 PESARAN, M.H., SHIN, Y. \& SMITH, R.J. (1996) "Testing for the Existence of a Long Run Relationship" DAE Working Paper No. 9622, Department of Applied Economics, University of Cambridge.

17 WICKENS, M.R. (1996) "Interpreting Cointegrating Vectors and Common Stochastic Trends" Journal of Econometrics, 74: 255-71. 